\section{New locality records of Rhacophorus lateralis Boulenger, 1883 (Amphibia: Anura: Rhacophoridae), in Western Ghats, India}

\author{
K.P. Dinesh'1, C. Radhakrishnan², K.V. Gururaja ${ }^{3}$ \\ \& Anil Zacariya ${ }^{4}$
}

1,2 Western Ghat Regional Centre, Zoological Survey of India, Kozhikode, Kerala 673006, India

${ }^{3}$ Centre for Infrastructure, Sustainable Transportation and Urban Planning (CiSTUP), Indian Institute of Science, Bengaluru, Karnataka 560012, India

4 'Beagle' Chandhkunnu, Kalpetta, Wyanad, Kerala 673121, India

Email: ${ }^{1}$ dineshcafe@gmail.com

Rhacophorus lateralis was described by Boulenger (1883) based on a single specimen (BM 82.2.10.75) from "Malabar" deposited at the British Museum. No further collections were available until Daniel Bennet and his team's rediscovery of the species from Coorg (Das 2000), Karnataka (ZSI A9071 and ZSI A9072). Das (2000) also removed the species from provisional synonymy with Rhacophorus malabaricus proposed by Wolf (1936).

Biju (2000) stated that Anil Zacariya (the fourth author of this account) located this species in 1980 from Kalpetta, Wyanad, Kerala and that subsequently in 1981 S.D. Biju observed 28 individuals of $R$. lateralis from Kalpetta. This species of tree frog was considered to be very rare, documented from Wyanad (Biju 2000) and Periyar Tiger Reserve (Easa 2003; Daniels 2005). In 2004, the

Date of publication (online): 26 June 2010

Date of publication (print): 26 June 2010

ISSN 0974-7907 (online) | 0974-7893 (print)

Editor: R.J. Ranjit Daniels

Manuscript details:

Ms \# 02209

Received 19 May 2009

Final received 27 May 2009

Finally accepted 29 May 2010

Citation: Dinesh, K.P., C. Radhakrishnan, K.V. Gururaja \& A. Zacariya (2010). New locality records of Rhacophorus lateralis Boulenger, 1883 (Amphibia: Anura: Rhacophoridae), in Western Ghats, India. Journal of Threatened Taxa 2(6): 986-989.

Copyright: (C) K.P. Dinesh, C. Radhakrishnan, K.V. Gururaja \& Anil Zacariya 2010. Creative Commons Attribution 3.0 Unported License. JoTT allows unrestricted use of this article in any medium for non-profit purposes, reproduction and distribution by providing adequate credit to the authors and the source of publication.

Acknowledgements: The authors are grateful to Dr. Ramakrishna Director, Zoological Survey of India, Kolkata for facilities and encouragement. We thank the anonymous referees and Sanjay Molur for the valuable suggestions and critical comments on the manuscript.

\section{OPEN ACCESS I FREE DOWNLOAD (C) (i) 凸}

IUCN assessed this species as Endangered and considered its range to be restricted to two small areas of Wyanad and Coorg in southern Western Ghats of India (Biju et al. 2004). Recently Biju (2009) and Goel \& Goel (2010) reported natural history studies in this species. Molur \& Molur (2010) reported this species from Shanthi Estate, Coorg.

On 04 March 1995, the second author observed a transforming young one (metamorph) of this species from the Shola forest patches of Eravikulam National Park, Kerala $\left(10^{\circ} 12^{\prime} 56^{\prime \prime} N\right.$ \& $\left.77^{\circ} 02^{\prime} 144^{\prime \prime E}\right)$. On 13 April 2005, during a survey in Wyanad, Kerala, the fourth author collected two specimens of the species from a coffee plantation at Kalpetta (11034'57'N \& 75059'34'E; ZSI/WGFRS/VIA 627a \& b). On 12 August 2006, the first author located five individuals of this species and collected one of them from a coffee plantation at Bygoor, (13018'59'N \& 75036'58'E) (V/A 667) Chikkamagaluru, Karnataka and on 14 August 2007 the first author saw four individuals and collected one representative specimen from Balehonnur (13018'03'N \& 75027'01' $\mathrm{E}$; V/A 678; Image 1a); both the localities are adjacent to Bhadra Tiger Reserve, Karnataka. On 25 July 2008 the third author located a few individuals of the species from a coffee plantation at Haramakki Estate, Kalasa (13018'02'N \& 75021'10"E; Image 1b), adjacent to the Kudremukh National Park, Karnataka. However, no specimens were collected.

We determined the identity of the four individuals collected (Table 1 ) as $R$. lateralis based on the following diagnostic features assigned to the taxon by Boulenger (1890) and Das (2000): habitus slender; head short, broader than long; snout short, obtusely pointed, projecting beyond mouth; canthus rostralis distinct; loreal region slightly concave; vomerine teeth in two small oblique series between the choanae; nostrils nearer to the tip of the snout than to the eye; interorbital space broader than the upper eyelid; eyes large; tympanum half the diameter of the eye; a supratympanic fold distinct; fingers and toes with enlarged disc possessing circummarginal grooves; fingers and toes with dermal fringes and more than half webbed; subarticular tubercles not very prominent; a fold of the skin bordering the forelimb anteriorly (Image $2)$; tibiotarsal articulation reaching the tip of the snout; dorsum smooth, belly granular; a prominent dorsolateral yellow streak on each side from the nostril to the groin along the outer edge of the upper eyelid.

A wide range of colour variation was noticed in the specimens collected and in individuals observed in the field (Image 1a and 1b). Both Boulenger (1890) and Das (2000) do not mention the variations in colour pattern in the species. Colour changes in this species are well recorded by Bennet et al. (2000), they attributed colour 

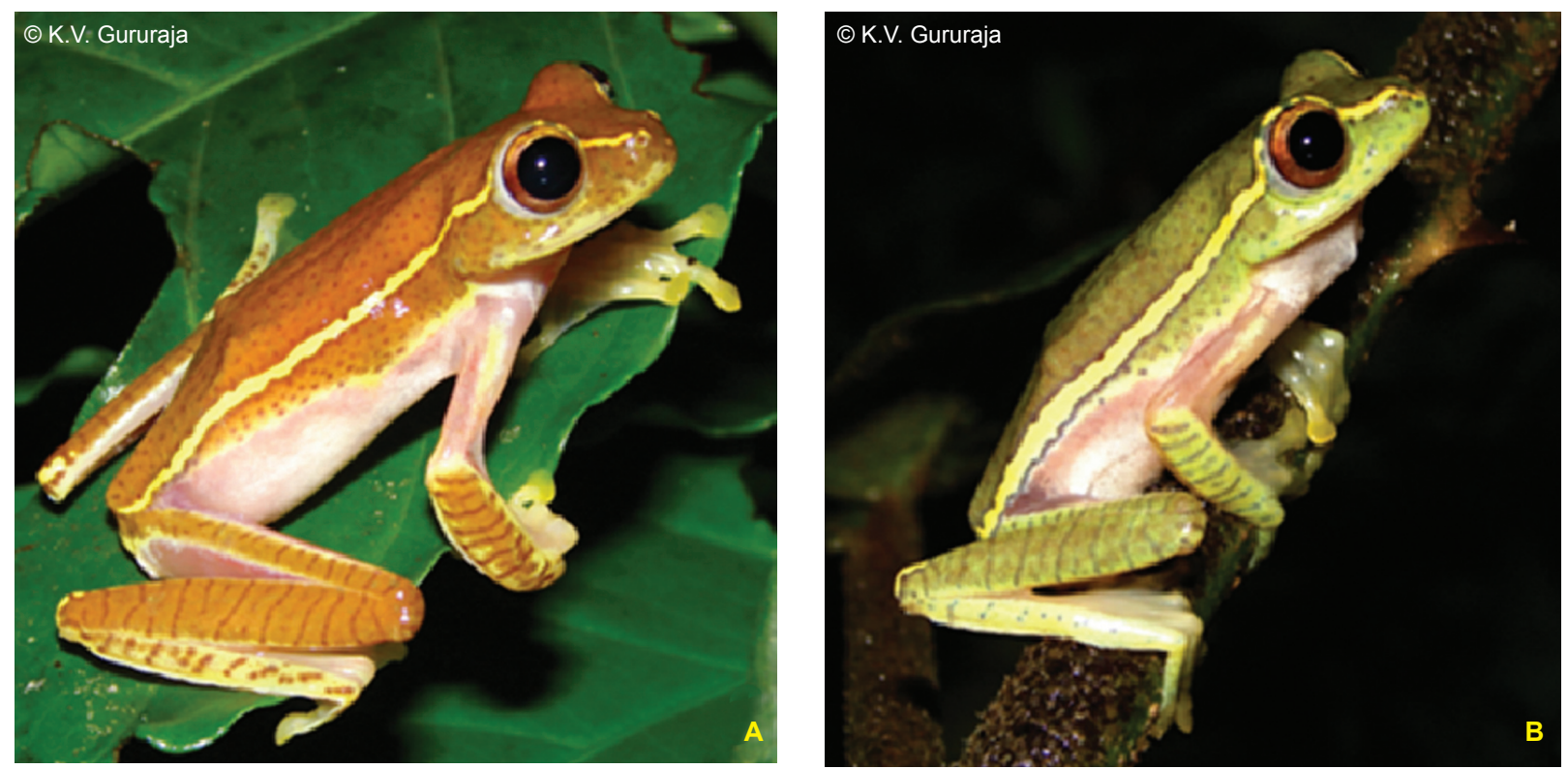

Image 1. Rhacophorus lateralis. A - with brown dorsum; B - with green dorsum

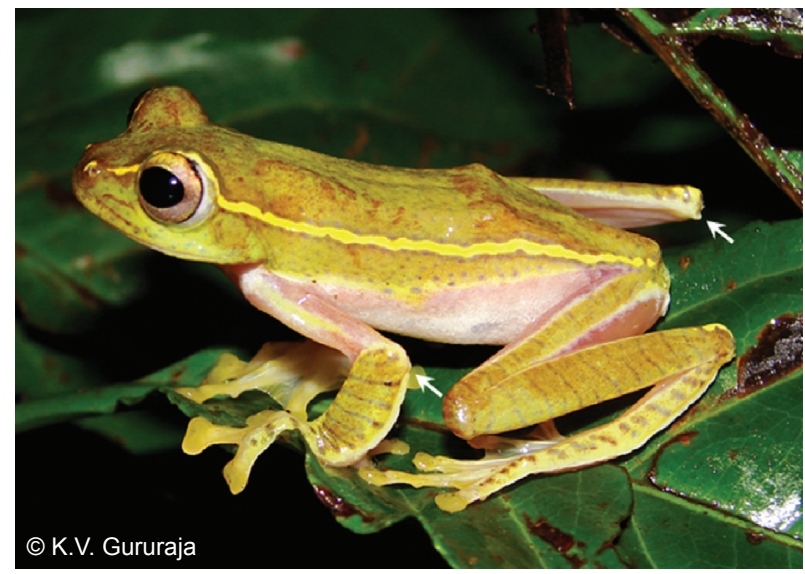

Image 2. Showing the prominent spurs on forelimb and hindlimb (indicated by arrows).

change to stress and Molur \& Molur (2010) found that the frequency and rapidity of colour change reduced after the individuals were handled repeatedly.

We noticed two colour morphs within the species, one morph with a dominantly green dorsum and the other with a brown dorsum with a mixture of varying shades of green. Our field observations confirmed that individuals of the species tend to change their body colour from time to time. Individuals with the green dorsum have the green colour interspersed with fine sky blue spots; a distinct metallic yellow lateral stripe running from the eye to the groin; a clear sky blue coloured line bordering either side of the yellow stripe; hind arm, lateral sides and ventral sides of the thigh with fleshy red to dark red colouration; fore arm and dorsal surface of the hind legs striped with broad green and narrow blue bands. The individuals with brown dorsum have darker brown spots; no demarcating blue line bordering the yellow stripe from the eye to the

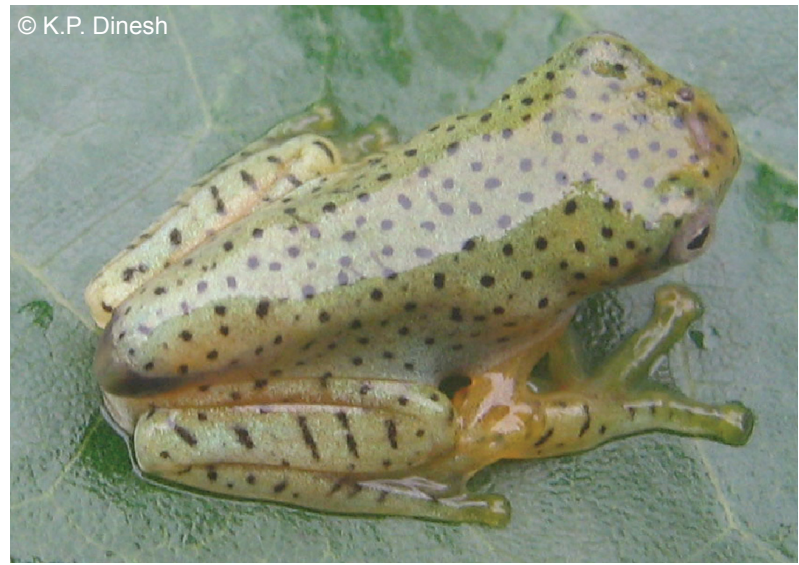

Image 3. Post-metamorphic tadpole of $R$. lateralis

groin; entire hind arm, lateral sides and ventral sides of the thigh, transparent; fore arm and dorsal surface of the hind legs striped with broad yellowish-green to brownishgreen and narrow dark brown or black bands. Notably, the one individual collected and the few individuals sighted in the field had the prominent spur in front of the joint of the hind arm and the forearm. We observed a post-metamorphic froglet (Image 3), which was green in colour with black spots over the dorsum and along the sides of the body having only the limbs barred without any distinctive dorsolateral yellow streak from the nostril to the groin along the outer edge of the upper eyelid.

In Wyanad, Bhadra Tiger Reserve and Kudremukh National Park, we noticed $R$. lateralis in association with $R$. malabaricus in the coffee plantations. Interestingly Molur \& Molur (2010) and Goel \& Goel (2010) noted the association of this species with $R$. malabaricus in Coorg area of coffee plantation and organic spice farm 
Table 1. Morphometric data of Rhacophorus lateralis.

\begin{tabular}{|c|c|c|c|c|c|c|c|}
\hline & $\begin{array}{c}\text { ZSI } \\
\text { A9071* }\end{array}$ & $\begin{array}{c}\text { ZSI } \\
\text { A9072* }\end{array}$ & $\begin{array}{l}\# V / A \\
627 a\end{array}$ & $\begin{array}{l}\# \text { V/A } \\
627 \mathrm{~b}\end{array}$ & \# V/A 667 & \# V/A 678 & $\begin{array}{l}\text { Average } \pm \text { standard } \\
\text { deviation (range) }\end{array}$ \\
\hline Snout-vent length & 29.5 & 32.0 & 28.0 & 29.0 & 30.4 & 31.4 & $30.1 \pm 1.51(28.0-32.0)$ \\
\hline Axilla-groin distance & 14.1 & 18.0 & 15.0 & 14.4 & 15.0 & 14.6 & $15.2 \pm 1.42(14.1-18.0)$ \\
\hline Head Length & 8.1 & 8.3 & 8.2 & 9.0 & 8.4 & 9.2 & $8.5 \pm 0.45(8.1-9.2)$ \\
\hline Head Width & 9.0 & 9.6 & 9.8 & 10.0 & 10.0 & 10.2 & $9.8 \pm 0.43(9.0-10.2)$ \\
\hline Head Depth & 5.6 & 5.3 & 6.2 & 7.0 & 7.0 & 6.4 & $6.3 \pm 0.70(5.3-7.0)$ \\
\hline Eye Diameter & 5.1 & 4.1 & 4.8 & 5.0 & 5.2 & 5.0 & $4.9 \pm 0.40(4.1-5.2)$ \\
\hline Upper eyelid width & 2.2 & 2.2 & 3.0 & 2.6 & 3.0 & 3.0 & $2.7 \pm 0.39(2.2-3.0)$ \\
\hline Interorbital distance & 3.5 & 5.8 & 4.2 & 4.0 & 4.2 & 4.2 & $4.3 \pm 0.78(3.5-5.8)$ \\
\hline Internarial distance & 2.8 & 2.5 & 3.0 & 3.4 & 3.0 & 2.4 & $2.9 \pm 0.37(2.5-3.4)$ \\
\hline Eye-snout-tip distance & 4.0 & 4.4 & 4.2 & 4.6 & 4.2 & 4.0 & $4.2 \pm 0.23(4.0-4.6)$ \\
\hline Eye-nostril distance & 2.3 & 2.5 & 3.4 & 3.4 & 3.0 & 3.0 & $2.9 \pm 0.45(2.3-3.4)$ \\
\hline Eye-tympanum distance & 0.6 & 0.7 & 1.0 & 1.0 & 0.6 & 0.4 & $0.7 \pm 0.24(0.6-1.0)$ \\
\hline Tibia length & 13.6 & 17.8 & 15.4 & 16.2 & 17.0 & 17.2 & $16.2 \pm 1.52(13.6-17.2)$ \\
\hline Disc diameter finger III & 1.5 & 1.5 & 1.4 & 2.0 & 2.0 & 1.6 & $1.7 \pm 0.27(1.4-2.0)$ \\
\hline Horizontal tympanum diameter & 1.5 & 1.6 & 1.8 & 2.0 & 1.4 & 1.4 & $1.6 \pm 0.24(1.4-2.0)$ \\
\hline Vertical tympanum diameter & 1.6 & 2.0 & 2.0 & 2.2 & 1.6 & 1.6 & $1.8 \pm 0.27(1.6-2.2)$ \\
\hline
\end{tabular}

* - from Das (2000); \# - ZSI/WGRC/VIA (Zoological Survey of India/Western Ghat Regional Centre/Vertebrata/Amphibia)

Table 2. Collection/sight localities of Rhacophorus lateralis in the Western Ghats

\begin{tabular}{|c|c|c|c|c|}
\hline Collection localities & $\begin{array}{l}\text { Latitude } \\
\text { (N) }\end{array}$ & $\begin{array}{l}\text { Longitude } \\
\text { (E) }\end{array}$ & $\begin{array}{l}\text { Date/Year of } \\
\text { sighting }\end{array}$ & Source/ Year of publication \\
\hline \multicolumn{5}{|l|}{ Karnataka } \\
\hline Bhadra Wildlife Sanctuary, Chikkamagaluru District & $13^{0} 18^{\prime}$ & $75^{\circ} 27^{\prime}$ & 12 August 2006 & present report \\
\hline Kudremukh National Park, Chikkamagaluru District & $13^{0} 11^{\prime}$ & $75^{0} 21^{\prime}$ & 25 July 2008 & present report \\
\hline Mojo Plantation, Coorg District & $12^{0} 28^{\prime}$ & $75^{\circ} 42^{\prime}$ & $2007-2009$ & Goel \& Goel 2010 \\
\hline Shanthi Estate, Coorg District & $12^{0} 24^{\prime}$ & $75^{\circ} 44^{\prime}$ & May 2005 & Molur \& Molur 2010 \\
\hline Luckunda Estate, Coorg District & $12^{\circ} 03^{\prime}$ & $76^{\circ} 02^{\prime}$ & 1998 & Bennet et al. 2000; Das 2000 \\
\hline \multicolumn{5}{|l|}{ Kerala } \\
\hline Kalpetta, Wyanad District & $11^{0} 34^{\prime}$ & $75^{\circ} 59^{\prime}$ & 1997 \& April 2005 & Biju 2000 and present report \\
\hline Eravikulam National Park, Idukki District & $10^{0} 12^{\prime}$ & $77^{\circ} 02^{\prime}$ & 4 March 1995 & present report \\
\hline Thekkady, Idukki District & $9^{0} 35^{\prime}$ & $77^{0} 12^{\prime}$ & Not available & Easa 2003 \\
\hline Periyar, Idduki District & $9^{0} 31^{\prime}$ & $77^{0} 15^{\prime}$ & 1990 & Biju 2000; Daniels 2005 \\
\hline
\end{tabular}

respectively. The species is being reported here for the first time from the surroundings of Bhadra Tiger Reserve and Kudremukh National Park, earlier record being Coorg in the central Western Ghats. Our report extends the range of the species further about $75 \mathrm{~km}$ (aerial distance) towards the north from Mojo Plantations, Coorg (Goel \& Goel 2010) in the Western Ghats. It appears that the species probably has wider distribution than what was known to us so far in the Western Ghats (Fig. 1).

\section{REFERENCES}

Bennet, D., K. Hampson, K. Sanders \& M. Anderson (2000). Frogs of Coorg, Karnataka, India. Final Report of the Aberdeen University Western Ghats Project, 1998.

Biju, S.D. (2000). 2 frogs and 100 years. Occasional Publication of the Indian Society for Conservation Biology (ISCB), Tropical Botanic Garden and Research Institute, Thiruvananthapuram, India, 14pp.

Biju, S.D. (2009). A novel nesting behaviour of a treefrog, Rhacophorus lateralis in the Western Ghats, India. Current Science 97(3): 433-437. 


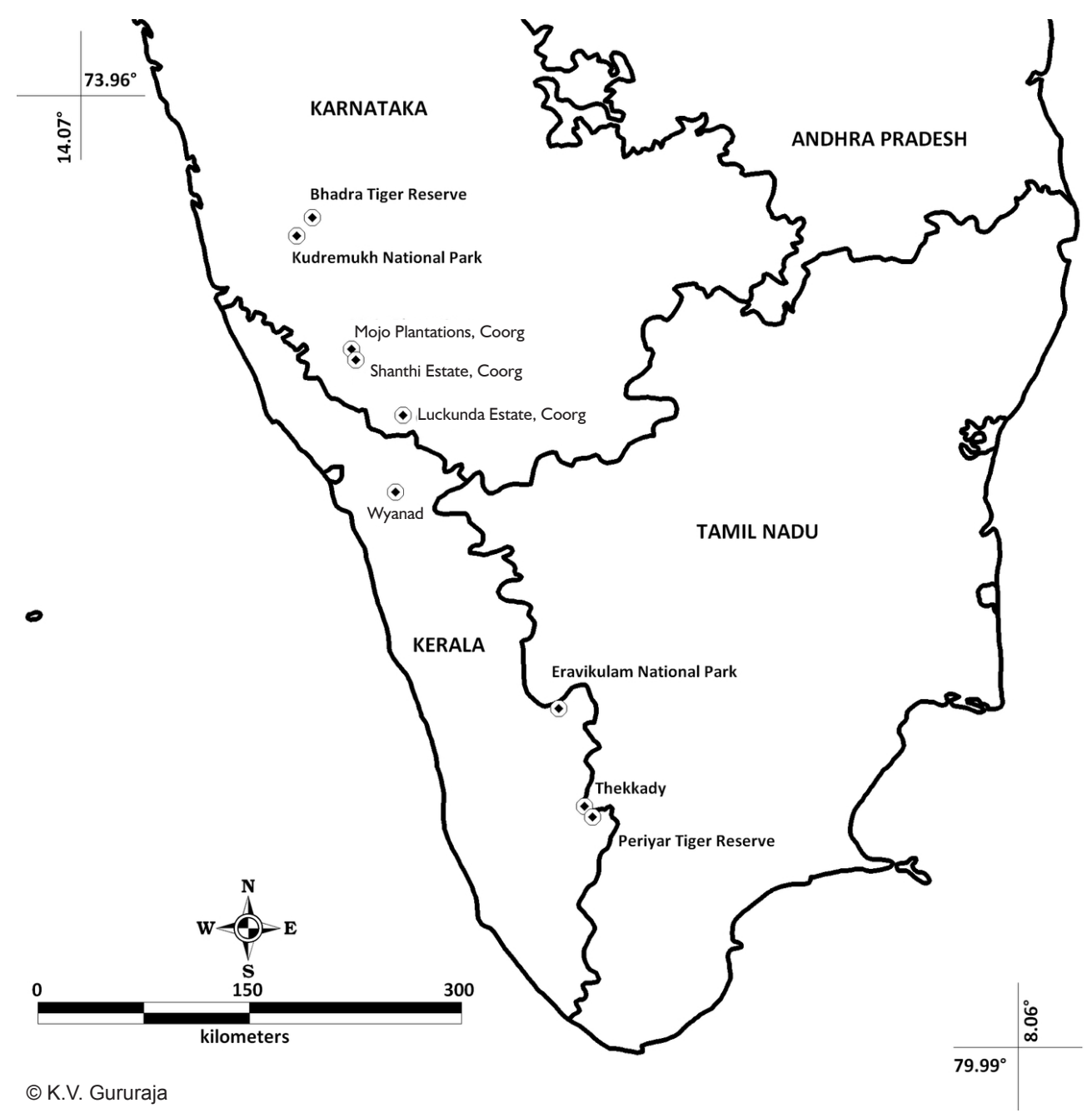

Figure 1. Map showing the locations where Rhacophorus lateralis has been recorded in Western Ghats

Biju, S.D., S. Dutta, K. Vasudevan, C. Srinivasulu \& S.P. Vijayakumar (2004). Rhacophorus lateralis. In: IUCN 2009. IUCN Red List of Threatened Species. Version 2009.2. $<w w w . i u c n r e d l i s t . o r g>$. Downloaded on 09 February 2010.

Boulenger, G.A. (1883). Description of new species of reptiles and batrachians in the British Museum. Annals and Magazine of Natural History 5(12): 161-167.

Boulenger, G.A. (1890). The Fauna of British India, including Ceylon and Burma. Reptilia and Batrachia. Taylor and Francis, London, xviii+451pp.

Daniels, R.J. (2005). Amphibians of Peninsular India. University Press (India) Private Limited, Hyderabad, 268pp.

Das, I. (2000). Nomenclatural history and rediscovery of Rhacophorus lateralis Boulenger, 1883 (Amphibia: Rhacophoridae). Current Herpetology 19(1): 35-40.
Easa, P.S. (2003). Amphibians, Part 9: Biodiversity documentation for Kerala. KFRI handbook No. 17: 35.

Goel, A. \& M. Goel (2010). Observations on Rhacophorus lateralis and $R$. malabaricus in northern Coorg. Frogleg, Newsletter of the Amphibian Network of South Asia and Amphibian Specialist Group South Asia 14: 8-10.

Molur, S. \& P. Molur (2010). Rhacophorus lateralis in Madikeri, Kodagu, Karnataka. Frogleg, Newsletter of the Amphibian Network of South Asia and Amphibian Specialist Group South Asia 14: 6-7.

Wolf, S. (1936). Revision der Untergattung Rhacophorus. Bulletin of the Raffles Museum 12: 137-217. 